\title{
Manajemen Aset Produktif untuk Memberdayakan Mustahik: Analisis Pendistribusian Zakat berdasarkan Fatwa MUI Nomor 14 Tahun 2011
}

\author{
Erik Rahman Gumiri \\ Universitas Islam Negeri Raden Intan Lampung, Indonesia \\ erikrahman@radenintan.ac.id \\ Abuzar Alghifari \\ Universitas Islam Negeri Raden Intan Lampung, Indonesia \\ abuzar@radenintan.ac.id
}

\begin{abstract}
Abstrack
Digital technology is increasingly fast and easy to create great opportunities for caring action and socio-philanthropic activities. This development has also become a motivation for zakat institutions in order to improve and increase their management activities oriented towards improving strategic management, so that their existence can continue and expand. All opportunities for new strategies and approaches are optimally absorbed and implemented so that they can be carried out without taking long. Coupled with the role of the state as a regulator by making laws and regulations and the implementation of zakat management run smoothly and orderly and further increasing the innovation of zakat management institutions, especially amil in its management, including the distribution of zakat benefits. Using a qualitative literature study research method, the researcher intends to analyze (1) Islamic law studies related to zakat management including distribution and utilization, then formulate (2) zakat empowerment strategies, so that (3) empowerment program designs for the poor are based on MUI Fatwa Number 14. 2011 concerning the Distribution of Zakat Assets in the Form of Managed Assets. Researchers obtained primary data sources through the interaction of online communication media with several devices in zakat institutions when researchers were doing internships. Secondary data comes from journal articles, scientific papers, and papers accessed via the internet. As a result, the preparation of empowerment program planning needs to pay attention to the provisions of the MUI Fatwa Number 14 of 2011 which applies and requires a mature management strategy in all series of activities, coupled with appropriate and competent resources, principles of innovation and full creativity in management so that program design can be realized in accordance with legal provisions regulating the optimal allocation of zakat assets so as to be able to grow an independent generation of dhuafa.
\end{abstract}

Keywords: Zakat Management; Empowerment Strategy Management; MUI Fatwa 


\section{Latar Belakang}

Seiring perkembangan tekhnologi, berbagai inovasi program pemberdayaan zakat terus digalakkan. Pembenahan sistem dari yang bersifat sektoral sampai pada non sektoral dilakukan sedimikian rupa. Hal ini tentu menjadi motivasi bagi lembaga zakat agar senantiasa memperbaiki dan meningkatkan kegiatan pengelolaannya dengan berorientasi menuju perbaikan, sehingga eksistensi terus dan semakin meluas. Segala peluang strategi dan pendekatan baru dalam manajemen, bisnis, finansial, hingga komunitas masyarakat mampu diserap dan diterapkan secara optimal dan dilakukan tanpa membutuhkan banyak waktu.

Pengelolaan zakat menjadi hal utama yang dibahas ketika “bagaimana langkah selanjutnya setelah berhasil menghimpun dana?". Seperti pada UU No. 38 Tahun 1999,1' Mengelola zakat yaitu aktivitas operasional mulai dari perencanaan, pelaksanaan sampai pengawasan pada kegiatan penghimpunan, penyaluran, serta pemanfaatan zakat. Pernyataan tersebut telah menjawab pertanyaan awal, bahwa langkah selanjutnya setelah berhasil menghimpun dana adalah menyalurkan kemanfaatannya. Berbekal kinerja manajemen lembaga pengelola zakat yang berkualitas, maka aktivitas pengelolaan zakat haruslah dapat diukur dengan 3 poin penting yakni amanah, sikap profesional, serta transparan. ${ }^{2}$

Berbicara penyaluran dengan kemanfaatan maksimal, penyaluran harus dilakukan dengan mengingat aspek kelembagaan, sumberdaya manusia, dan manajemen terbuka dengan perencanaan aktivitas yang matang, target/ sasaran yang sesuai, manajemen finansial yang selalu siap diaudit, sistem publikasi yang strategis hingga rancangan perbaikan yang rutin berkala. Hal tersebut diwujudkan dalam pola distribusi zakat dari donatur ditujukan untuk mustahik melalui pengelola (amil). ${ }^{3}$ Pola berarti gambaran, cara kerja, struktur. Pola pendistribusian tidak hanya satu. Hal ini disebabkan dinamisnya perkembangan dunia filantropi, sehingga lahir pola tradisional -dikenal dengan pola konsumtif- dan pola kontemporer pola produktif-. Jika membicarakan perkembangan dunia filantropi maka akan lebih tepat untuk lanjut membahas pola kontemporer. Bentuk pola kontemporer yakni pendayagunaan. KBBI mendefinisikan Pendayagunaan sebagai suatu tindakan yang diusahakan guna

\footnotetext{
${ }^{1}$ Undang-Undang Republik Indonesia Nomor 38 Tahun 1999 Tentang Pengelolaan Zakat

2 Yandi Bastiar (2019), "Model Pengukuran Kinerja Lembaga Zakat di Indonesia”, ZIZWAF: Jurnal Zakat dan Wakaf, 6(1), 43-63.

${ }^{3}$ I.S. Beik; L.D. Arsyianti (2016), "Measuring Zakat Impact on Poverty and Welfare Using CIBEST", Journal of Islamic Monetary Economics and Finance, 1(2), 141-160.
} 
mendatangkan hasil dan manfaat jika dilakukan dengan baik. Dalam praktiknya, pendayagunaan zakat yang ditujukan untuk mustahik terbagi menjadi dua jenis: (1) Program Charity yaitu program amal. Model program ini adalah wujud penyaluran sesaat. Mustahik yang menerima program ini termasuk dalam prioritas mustahik yang memerlukan bantuan langsung untuk memenuhi kebutuhan hidupnya. Target yang dibuat juga sederhana yaitu untuk menyelesaikan persoalan mustahik yang bersifat segera atau mendesak. Bantuan yang diberikan dapat segera ditunaikan ketika syarat dan ketentuan terpenuhi sehingga tidak membutuhkan skema pemberdayaan. ${ }^{4}$ Lalu, (2) Program Pemberdayaan yaitu program yang berorientasi pada kemanfaatan jangka panjang. Program ini juga yang sering digunakan untuk mengubah mustahik hingga mampu menjadi muzaki. ${ }^{5}$

Namun dikarenakan program ini memerlukan berbagai rangkaian aktivitas maka waktu dan strategi yang diperlukan harus matang mulai dari perencanaan, pengkajian, pengaplikasian, sampai pada monitoring dan evaluasinya. Disinilah kemampuan pengelola program menjadi penentu. Manajemen strategi dalam mengatur segala perencanaan program harus disiapkan dengan kemampuan yang berkompeten. Termasuk dalam penentuan target/ sasaran. Diketahui bahwa golongan mustahik terbagi menjadi dua berdasarkan konteksnya yakni Pertama, mustahik permanen : fakir, miskin, amil, serta muallaf. Dikatakan permanen karena mustahik golongan ini diasumsikan selalu ada dalam ruang lingkup kerja lembaga pengelola zakat meskipun penerimanya tidak selalu sama. Kedua, mustahik temporer : ghorim, ibnu sabil, riqob, dan fisabilillah dikarenakan golongan ini jarang dijumpai selama lingkup kerja lembaga pengelola berjalan. ${ }^{6}$

Masih dalam pembahasan mengelola harta zakat di Indonesia, negara berfungsi menjadi regulator dengan tugas membuat peraturan termasuk perundang-undangan dan pelaksanaan terkait pengelolaan zakat.7 Undang-undang yang tentu terlintas dalam ingatan terkait zakat pasti Undang-undang Nomor 38 Tahun 1999 yang diubah dan diperbaiki dengan Undang-undang Nomor 23 Tahun 2011 terkait mengelola zakat yang kemudian dikeluarkannya Peraturan Pemerintah nomor 14 tahun

\footnotetext{
${ }^{4}$ A.A. Habib (2016), "The Principle of Zakat, Infaq and Shadaqah Accounting Based SFAS 109", Jorunal of Acounting and Bussines, 1(1), 21-37.

${ }^{5}$ H. Shabri (2014), "Performance Comparison Amil Zakat Institutions Managed by the Government and Private Organization in West Sumatra Province", Jurnal Performance, 1(1), 103-107.

${ }^{6}$ Rosi Rosmawati (2014), "Pengembangan Dana Zakat Produktif Melalui Lembaga Amil Zakat (LAZ) untuk Meningkatkan Kesejahteraan Masyarakat", PJIH: Jurnal Ilmu Hukum, 1(1), 10.

7 Mustafa Lutf (2020), "Peran Negara dalam Optimalisasi Zakat Perspektif Konstitusi Ekonomi", Jurnal of Family Studies, 1(1), 7.
} 
2014 sebagai aturan pelaksanaannya. Harapan dibuatnya segala bentuk aturan terkait pengelolaan zakat tersebut ialah demi kelancaran pelaksanaan kewajiban seorang muslim dalam agama islam, sehingga dapat dijalankan secara tertib. ${ }^{8} \mathrm{Hal}$ ini juga salah satu bentuk pelayanan oleh negara sebagai fasilitator warga negaranya. Seiring perkembangan zaman tentunya lahir juga berbagai peraturan hukum islam yang lain untuk melengkapi aturan dasar tersebut. Aturan yang lahir dari jalan ijtihad para ulama islam turut menyempurnakan pengelolaan zakat seperti melalui Fatwa Majelis Ulama Islam nomor 14 tahun 2011 terkait Penyaluran Harta Zakat dalam Bentuk Aset Kelolaan. Aset kelolaan yang dimaksud yakni berupa sarana dan prasana untuk para mustahik. Sarana dan prasana tersebut tentunya dapat menjadi objek dalam program pemberdayaan oleh lembaga pengelola zakat. Program yang akan dirancang nantinya dapat menjadi salah satu bentuk inovasi dalam kegiatan pengelolaan. Ulasan tersebut membuat peneliti tergugah untuk membahas lebih spesifik lagi terkait rancangan program pemberdayaan zakat bagi mustahik sebagaimana Fatwa MUI yang berlaku.

\section{Kajian Pustaka}

\section{Ulasan Zakat dan Amil Zakat}

Zakat merupakan harta yang mengandung persyaratan khusus berdasarkan Al-Quran dan Hadits yang mewajibkan pemiliknya untuk memberikan sebagian tersebut kepada yang berhak menerima namun juga dengan persyaratan khusus. ${ }^{9}$ Definisi tersebut mengingat adanya Q.S. An-Nur ayat 56 yang artinya: "Dan dirikanlah shalat, tunaikanlah zakat, serta taat kepada rasul, supaya diberi rahmat". Ayat ini menyiratkan bahwa kekuatan wajib dalam berzakat dan mengelola zakat sangat kuat, sama seperti shalat wajib yang selalu bergandengan dengan kewajiban zakat.

Sedangkan arti zakat dalam UU No 23 Tahun 2011 merupakan kewajiban agama seorang muslim yang mampu, terkait kekayaan yang dimiliki untuk ditunaikan kepada yang berhak menerima demi kehidupan yang lebih sejahterah dan sesuai syariah islam. ${ }^{10}$ Perintah tersebut diulas dalam Q.S. al-Taubah ayat 103 yang berarti: "Ambillah zakat dari sebagian harta mereka, dengan zakat itu kamu membersihkan dan mensucikan mereka...". Ayat tersebut menggambarkan tentang perintah Allah

\footnotetext{
8 Basar Dikuraisyin (2019), “Kompetensi Amil, Persyaratan Sampai Pelaporan: Analisis Efektifitas UU Nomor 23 Tahun 2011 di Lembaga Zakat Jawa Timur", MAZAWA: Management of Zakat and Waqf Journal, 1(1), 1-2.

${ }^{9}$ Didin Hafidhuddin. Zakat Dalam Perekonomian Modern, (Jakarta : Gema Insani, 2002), 7.

${ }^{10}$ Andri Soemitra, Bank dan Lembaga Keuaga Syariah, (Jakarta: Kencana, 2009), 403.
} 
untuk melakukan pengelolaan zakat. Sehingga zakat dan pengelolaannya samasama keharusan. ${ }^{11}$

Berbicara tentang orang-orang atau kelompok yang berhak menerima harta juga telah dijelaskan dalam Q.S At-Taubah ayat 60 yang artinya: "Sesungguhnya zakat hanyalah untuk orang fakir, miskin, amil zakat, mualaf (yang melunak hatinya), untuk membebaskan hamba sahaya, melunaskan orang yang berhutang, untuk yang berada di jalan Allah dan untuk orang yang sedang di dalam perjalanan sebagai kewajiban dari Allah. Allah Maha Mengetahui lagi Maha Bijaksana."12

Dari arti surah tersebut diketahui terdapat 8 kelompok yang berhak menerima zakat yakni Fakir, Miskin, Gharim, Mualaf, Amil, Riqab, Fisabilillah dan Ibnu Sabil. ${ }^{13} 8$ kelompok penerima zakat tersebut dalam UU no. 23 tahun 2011 disebut sebagai Mustahik. Sedangkan seorang muslim yang wajib mengeluarkan harta zakat setelah mencukupi kebutuhan pokoknya disebut sebagai Muzaki, baik dari perorangan pribadi, secara kelompok maupun badan usaha. Sebagaimana dalam Q.S. al-Baqarah ayat 2 yang artinya: "...dan mereka bertanya kepadamu apa yang mereka nafkahkan. Katakanlah: yaitu yang lebih dari keperluan..."

Serta hadist riwayat Bukhari: "Dari Hakim bin Hizam r.a., dari Nabi saw, bersabda: "Tangan atas lebih baik dari tangan bawah. Mulailah (membelanjakan harta) pada orang yang menjadi tanggung jawabmu. Sedekah paling baik adalah yang ditunaikan dari kelebihan kebutuhan. Barang siapa yang menjaga dirinya dari keburukan, maka Allah menjaganya. Dan barang siapa berusaha mencukupi diri, Allah memberinya kecukupan"

Ditunaikannya zakat adalah dengan diserahkan kepada pihak pengelola zakat baik perorangan/ kelompok yang dibentuk/ diangkat/ diresmikan oleh pemerintah dalam pelaksanaan kelolaan zakat yaitu amil zakat. ${ }^{4}$ sebagaimana hadist Rasulullah: ${ }^{15}$ "Nabi Muhammad ketika mengutus Muadz ke Yaman bersabda: ... Dan beritahukan mereka bahwa Allah SWT mewajibkan berzakat yang diambil dari harta orang kaya dan dikembalikan kepada para fakir". (HR Bukhari dan Muslim dari Ibnu Abbas).

Dan juga, "Rasulullah saw menugaskan seorang laki-laki bani Al-Asdi bernama Ibnu Al-Lutbiyyah sebagai amil zakat untuk daerah bani Sulaim, kemudian Rasul melakukan evaluasi tugas yang telah dilaksanakan". (HR Bukhari dan Muslim dari Abi Humaid Al-Saa'idy).

\footnotetext{
${ }^{11 E f r i ~ S y a m s u l ~ B a h r i ; ~ S a b i k ~ K h u m a i n i ~(2020), ~ “ A n a l i s i s ~ E f e k t i v i t a s ~ P e n y a l u r a n ~ Z a k a t ~ p a d a ~ B a d a n ~}$ Amil Zakat Nasional", al-Maal: Jorunal of Islamic Economics and Banking, 1(2), 157.

${ }^{12}$ Depag RI, Al Quran dan Terjemahan, (Bandung: CV Diponegoro, 2000), 184.

${ }^{13}$ Mufraini Arif. Akuntansi dan Manajemen Zakat, (Jakarta: kencana, 2006), 154.

${ }^{14}$ Fatwa MUI nomor 8 tahun 2011 tentang Amil Zakat, 4.

${ }^{15}$ Ibid, 2.
} 
Seseorang yang dipilih menjadi amil zakat bukan sembarangan, terdapat beberapa indikator yang harus dipenuhi oleh seorang amil zakat meliputi sifat Amanah dan tentunya beragama islam, mukallaf yaitu telah baligh dan berakal, memiliki ilmu pengetahuan terkait hukum dunia zakat sehingga dalam menjalankan tugasnya dapat dilakukan dengan optimal. ${ }^{16}$ Beberapa tugas umum seorang amil antara lain melakukan pengumpulan zakat melalui kegaitan pendataan muzaki, memahami ketentuan objek zakat, mengetahui ukuran nishab dan tarif zakatnya serta syarat-syarat pada setiap objek zakatnya. Selanjutnya melakukan pemeliharaan zakat melalui aktivitas inventarisasi dan pengamanan terhadap harta zakat. Serta yang paling penting adalah pendistribusian zakat. Pendistribusian zakat ini dapat dilakukan dengan berbagai jalan hingga benar-benar sampai pada mustahik yang tepat.

Segala biaya aktivitas untuk mengelola zakat yang dilakukan oleh amil telah diatur oleh Ulil Amr (Pemerintah). ${ }^{17}$ Namun, apabila biaya yang telah disediakan oleh Ulil Amr tersebut belum mencukupi maka amil diperkenankan untuk mengambil dari hasil pengumpulan zakat pada dana Amil atau dari dana Fisabilillah dan tetap pada ukuran yang wajar. Hal ini berarti setiap dana yang dikelola oleh amil harus dapat dipertanggung jawabkan sesuai pada peruntukkannya. Ketentuan lain bagi amil yaitu dilarang menerima hadiah dari muzaki dalam hal yang berkaitan dengan tugasnya dan juga sebaliknya, amil dilarang memberi hadiah kepada muzaki menggunakan dana zakat yang dikelolanya. Hal ini berarti dalam pengelolaan dana zakat harus benar-benar diperuntukkan untuk mustahik yang membutuhkan, sehingga menghindari penggunaan dana zakat untuk kepentingan amil pribadi. Apabila mustahik telah tercukupi dengan pemberian zakat maka zakat harus diberikan kepada mustahik yang lain agar setiap mustahik dapat menerima bagiannya secara adil dan merata sebagaimana pada aturan syariah dan aturan hukum yang telah ditetapkan.

\section{Pengelolaan Zakat: Penyaluran dan Pendayagunaan}

Zakat dalam Undang-Undang Nomor 23 Tahun 2011 yaitu harta yang wajib ditunaikan seorang muslim baik pribadi, kelompok maupun badan hukum kepada pihak yang berhak menerima sesuai dengan aturan syariah yang berlaku. Sedangkan dalam undang-undang dijelaskan juga bahwa pengelolaan zakat dapat diartikan sebagai kegiatan manajerial

\footnotetext{
${ }^{16}$ Mohamad Ridwan; Lilis Andalasari; Reka Indah Setiani; Rizka Merliana (2020), "Pengelolaan Zakat Produktif melalui Program Senum Mandiri dalam Pemberdayaan Ekonomi Mustahiq di Rumah Zakat Cabang Cirebon", Ecobankers: Journal of Economy Banking, 1(2), 12-17.

${ }^{17}$ Ibid, 4-5.
} 
mulai dari perencanaan, pelaksanaan, hingga pengkoordinasian dalam rangka menghimpun, mendistribusikan, serta mendayagunakan harta zakat. $^{18}$

Proses pengelolaan zakat harus berdasarkan aturan syariah islam yang berlaku, selalu berpegang pada prinsip amanah terhadap harta yang dikelola, senantiasa mengelola kemanfaatan dengan prinsip keadilan yang mana dalam pengelolaan tersebut juga mengandung kepastian hukum didalamnya sehingga segala kegiatan pengelolaan dapat selalu terintegrasi dan dikelola secara akuntabilitas. Pengelolaan zakat tersebut tentu dilakukan untuk suatu tujuan, yakni untuk meningkatkan pelayanan zakat yang efektif dan efisien, serta memelihara kemanfaatan zakat demi kesejahteraan juga sebagai upaya mengurangi kemiskinan. Berbekal kinerja manajemen yang berkualitas, maka aktivitas pengelolaan zakat haruslah dapat diukur dengan 3 poin penting yakni Amanah, Sikap Profesional, serta Transparan. ${ }^{19}$

Lantas, bagaimana langkah pengelolaan selanjutnya setelah berhasil menghimpun dana? Sesuai dengan UU No. 38 Tahun 1999 bahwa mengelola zakat yaitu aktivitas operasional mulai dari perencanaan, pelaksanaan sampai pengawasan pada kegiatan penghimpunan, penyaluran, serta pemanfaatan zakat. Pernyataan tersebut telah menjawab pertanyaan awal, bahwa langkah selanjutnya setelah berhasil menghimpun dana adalah menyalurkan kemanfaatannya. ${ }^{20}$ Penyaluran dengan kemanfaatan maksimal harus dilakukan dengan mengingat aspek kelembagaan, sumberdaya manusia, dan manajemen terbuka dengan perencanaan aktivitas yang matang, target/ sasaran yang sesuai, manajemen finansial yang selalu siap diaudit, sistem publikasi yang strategis hingga rancangan perbaikan yang rutin berkala. Hal tersebut direalisasikan dalam pola pendistribusian zakat yakni penyaluran zakat dari muzaki kepada mustahik melalui amil. Pola diartikan sebagai gambaran, cara kerja atau struktur. Pola distribusi zakat terbagi menjadi dua (2) yaitu pola tradisional (konsumtif) dan pola kontemporer (produktif). Pola konsumtif merupakan jenis penyaluran yang kemanfaatannya habis pakai. ${ }^{21}$ Sedangkan pola produktif merupakan penyaluran yang tidak hanya sekali pakai namun bisa dikelola agar

\footnotetext{
${ }^{18}$ Undang-Undang Republik Indonesia Nomor 23 Tahun 2011 Tentang Pengelolaan Zakat

19 Muhammad Izzuddin Abdul Aziz; Heru Susetyo (2020), “Dinamika Pengelolaan Zakat oleh Negera di Beberapa Provinsi di Indonesia Pasa Undang-Undang No. 23 tahun 2011", Jrnal Hukum dan Pembangunan, 49(4), 968-977.

${ }^{20}$ Hafizah Zaini (2016), "Managing Zakat Fund in Malaysia", Journal of Gloal Businiess and Social Entreprenuership, 1(2), 47.

${ }^{21}$ Irfan Syauqi Beik (2009), "Alanysis of the Role of Zakat in Reducing Poverty”, Research Gate, 2(1), 4-5.
} 
kemanfaatan dapat terus dirasakan. Salah satu upaya pola produktif yaitu aktivitas pendayagunaan. Pendayagunaan berasal dari kata "guna" sehingga seraca konseptual merupakan suatu tindakan yang diusahakan agar mendatangkan hasil dan manfaat apabila dilakukan dengan strategi yang benar.

Praktiknya pada pengelolaan zakat, pendayagunaan yang ditujukan untuk para mustahik terbagi menjadi dua macam yaitu Program Charity atau program amal. Model programnya adalah penyaluran sesaat. Mustahik yang menerima adalah yang termasuk dalam golongan prioritas yaitu yang memerlukan bantuan langsung untuk memenuhi kebutuhan hidupnya. Target yang dibuat juga sederhana hanya untuk menyelesaikan persoalan mustahik yang bersifat segera atau mendesak. Bantuan yang diberikan dapat segera ditunaikan ketika syarat dan ketentuan terpenuhi sehingga tidak membutuhkan skema pemberdayaan. ${ }^{22}$ Lalu Program Pemberdayaan yaitu yang berorientasi pada kemanfaatan jangka panjang. Program ini terkenal digunakan untuk mengubah mustahik menjadi muzaki. Namun dikarenakan program ini memerlukan berbagai rangkaian aktivitas maka diperlukan waktu dan strategi matang dalam rangkaian aktivitasnya. Kemampuan pengelola program menjadi penentu dalam hal ini. Manajemen strategi dalam mengatur segala perencanaan program harus disiapkan dengan kemampuan yang kompeten. ${ }^{23}$ Salah satunya dalam penentuan target/ sasaran. Telah banyak diketahui bahwa golongan mustahik terbagi menjadi dua berdasarkan konteksnya yakni Pertama, mustahik permanen : fakir, miskin, muallaf, dan amil. Dikatakan permanen karena mustahik golongan ini diasumsikan selalu ada dalam ruang lingkup kerja lembaga zakat meskipun penerimanya tidak selalu sama. Kedua, mustahik temporer/ musiman : ghorim, ibnu sabil, riqob, dan fisabilillah dikarenakan golongan ini jarang dijumpai selama lingkup kerja lembaga pengelola berjalan.

Jadi konsep pendayagunaan lebih sering dipakai untuk golongan mustahik permanen. Hal ini dilakukan untuk mengurangi jumlah mustahik permanen melalui program-program pemberdayaan. UU no. 23 tahun 2011 juga menerangkan, zakat bisa digunakan untuk pendayagunaan usaha produktif guna meningkatkan kehidupan umat, utamanya fakir miskin apabila kebutuhan dasar mustahik telah

\footnotetext{
22 Shafiqul Hasan (2017), “Persecuted Muslim Minority: Zakat, Waqf and Sadaqah as Financial Instrument for Human Development", International Journal of Applied Business and Economic Research, 2(2), 12.

${ }^{23}$ Dian Mashita (2018), "Pelajaran dari Manajemen Zakat dari Berbagai Era dan Negara al-Iqtisha", Jurnal Ilmu Ekonomi Syariah, 10(2), 17-20.
} 
tercukupi. ${ }^{24}$ Namun apabila masih terdapat mustahik yang membutuhkan dana zakat untuk kebutuhan yang bersifat segera, maka lebih baik ditunaikan terlebih dahulu.

\section{Manajemen Strategi Pemberdayaan}

Manajemen direalisasikan sebagai serangkaian kegiatan sistematis mulai dari perumusan/ perencanaan, lalu penggolongan/ pengelompokkan, selanjutnya tindakan/ pelaksanaan, hingga pengendalian/ pengawasan pada suatu target sasaran dan tujuan yang sengaja dibuat dengan mengoptimalkan sumberdaya yang dimiliki secara terkontrol dan bijak. ${ }^{25}$ Kegiatan yang sistematis tersebut dijabarkan secara terperinci mulai dari (1) Perencanaan yaitu sebuah pemikiran, perumusan, dan penetuan langkah-langkah terhadap sesuatu yang akan dikerjakan. Terbagi menjadi dua: Pertama, rencana strategik yaitu pemikiran yang sengaja dirancang yang mengandung sebuah tujuan luas beserta realisasi langkah-langkah guna mewujudkan tujuan tersebut. Kedua, rencana operasional yaitu perincian langkah-langkah dari rencana strategik yang akan dicapai. Jenis rencana operasional terbagi dua; (a) rencana sekali pakai yakni setelah rencana ini terwujud maka pemikiran yang telah digunakan tidak digunakan lagi (single use plans); dan (b) rencana tetap yakni pemikiran yang telah digunakan apabila telah terbukti berhasil, maka tetap digunakan kembali karena diperkirakan terdapat beberapa tujuan lain yang sesuai apabila menggunakan pemikiran ini kembali (standing plans). ${ }^{26}$

Selanjutnya, (2) Pengorganisasian yaitu proses dikelompokkannya sumber-sumber daya secara teratur sehingga menghasilkan sebuah pekerjaan dengan tanggung jawab hingga terbentuknya sebuah struktur sebagai bentuk kesatuan demi tercapainya tujuan. Pengorganisasian terbagi menjadi dua arti: Pertama, arti statis yaitu sebagai skema yang menggambarkan hubungan meliputi fungsi, tugas hingga tanggung jawab secara keseluruhan. Kedua, arti dinamis yaitu pembagian tugas-tugas kepada tiap individu maupun kelompok guna mempermudah pencapaian tujuan. Lalu, (3) Pelaksanaan yaitu keseluruhan langkah-langkah meliputi usaha, cara, teknik dan metode yang dikerjakan dengan maksimal demi pencapaian tujuan yang efektif, efisien serta bernilai guna. Dan (4) Pengawasan yaitu kegiatan yang dilakukan oleh atasan dengan

\footnotetext{
${ }^{24}$ UU nomor 23 tahun 2011 pasal 27 tentang Pendayagunaan

25 Efri Syamsul Bahri; Zainal Arif (2020), “Analisis Efektifitas Penyaluran Zakat pada Rumah Zakat", al-Maal: Journal of Islamic Economics and Banking, 2(1), 13-24.

26 Sabik Khumaini; Anto Apriyanto (2018), “Pemberdayaan Dana Zakat Produktif terhadap Kesejahteraan Umat", Jurnal al-Urban, 2(1), 32-42.
} 
mengamati perkembangan bawahannya dalam melaksanakan rencana, langkah-langkah dan kebijakan dalam merealisasikan tujuan yang telah ditetapkan. ${ }^{27}$

Sedangkan, Strategi diartikan sebagai perencanaan ${ }^{28}$ yakni rumusan yang dibuat secara sistematik melalui langkah-langkah yang berorientasi pada masa depan berdasarkan pertimbangan yang matang terkait potensi hingga faktor-faktor terpenting guna mencapai suatu tujuan. Prinsip terpenting dalam perencanaan didapat dari 5W1H, yakni : (1)What, Apa visinya? Apa misinya?; (2)Why, Mengapa memilih melakukannya?; (3)Who, Siapa saja yang terlibat? Siapa yang bertanggungjawab?; (4)Where, Dimana dilakukannya? Dimana terjadinya; (5)When, Kapan dilakukannya? Berapa lama melakukannya?; (6)How, Bagaimana cara melakukannya? Bagaimana sumberdaya didapatkan?.

Setiap langkah yang telah dirumuskan tetap harus mengacu pada misi yang telah dibuat. Jika tidak maka langkah tersebut telah keluar dari misi sehingga kegiatan menjadi tidak terarah pada tujuan atau visinya. Namun, misi juga perlu untuk senantiasa dievaluasi dan harus dapat bersifat dinamis karena seiring perkembangan zaman perlu untuk menyesuaikan dengan situasi dan kondisi lingkungan sekitar. Strategi diartikan juga sebagai pola kegiatan berupa proses timbal balik dan penyesuaian. Artinya, pola kegiatan ini berperan sebagai sinkronisasi antara tujuan sesuai visi dengan tindakan sesuai misi, sehingga hubungan antar keduanya selalu bisa disesuaikan dan dievaluasi untuk dijadikan indikator keberhasilan nantinya. Terakhir, strategi diartikan sebagai rekayasa atau rahasia. Penyusunan strategi memerlukan seni dalam menata langkah-langkah dengan baik agar tujuan dapat dengan mudah dicapai. ${ }^{29}$ Dari dua pengartian tersebut maka makna manajemen dengan strategi adalah serupa, jika manajemen membicarakan dari sudut teori maka, strategi dari sudut tindakan atau praktek. Sehingga apabila keduanya dapat dijalankan bersamaan dengan baik maka suatu sasaran atau tujuan yang dibuat dapat segera tercapai

Berbicara tentang pemberdayaan, ditinjau dari sisi konseptual pemberdayaan dapat disama-artikan dengan kekuasaan. ${ }^{30}$ Kekuasaan

\footnotetext{
27 Nasrullah (2019), “Filantropi Islam: Praktek dan Konstibusinya terhadap Ketercapaian Sustainable Development Golas (SDGs)", in Annual Conference for Muslim Scolars, Surabaya, 364375.

${ }^{28}$ Aminah, Siti. 2014. Perumusan Manajemen Strategi Pemberdayaan Zakat. Jurnal Hukum Islam (Jhi). Volume 12 (No.1): 88

29 Dewi Susilowati; Christina Tri Setyorini (2018), “Efektivitas Tata Kelola Dana Zakat", Jurnal Akuntansi Multiparadigma, 9(2), 364-375.

${ }^{30}$ Nuraeni, Irma (2018), "Pemberdayaan Potensi Sosial Masyarakat Muslim Melalui Yayasan Aksi Cepat Tanggap (ACT) Bandung", Anida: Aktualisasi Nuansa Ilmu Dakwah, 18 (1): 89.
} 
berarti kemampuan untuk menjadikan orang lain mau melakukan suatu keinginan, namun terlepas dari minat mereka. Jika ditelaah, terdapat keterkaitan antara pemberdayaan dengan kekuasaan. Pertama, kekuasaan dapat berubah, jika tidak maka pemberdayaan tidak dapat terjadi. Kedua, kekuasaan dapat diperluas, sehingga wujud pemberdayaan memiliki sasaran yang mampu menjangkau segala hal. Arti kekuasaan dalam hal ini yaitu dinamis, maka upaya pemberdayaan dapat diubah dan diperluas sesuai kebutuhan dan keadaan yang terjadi. Pemberdayaan juga merupakan serangkaian aktivitas guna mengubah kondisi suatu kelompok yang lemah menuju kondisi yang lebih sejahterah dengan mengupayakan sebuah hasil yang ingin dicapai dimasa depan. ${ }^{31}$ Sehingga dapat disimpulkan bahwa manajemen strategi pemberdayaan adalah serangkaian pemikiran dan langkah sistematis yang bertujuan untuk mendorong dan membuat suatu perubahan yang ditujukan kepada suatu kelompok pada kondisi tertentu kearah kondisi yang lebih sejahterah dari sebelumnya.

\section{Metode Penelitian}

Penelitian ini menggunakan metode studi kepustakaan kualitatif dimana objek penelitiannya didapatkan dari pengalaman peneliti yang selanjutnya ditelaah dengan beberapa bacaan deskriptif seperti bukubuku elektronik (E-book), karya ilmiah, jurnal, media internet, dan sumbersumber lainnya. Alasan peneliti menggunakan metode tersebut dikarenakan metode studi kepustakaan kualitatif ${ }^{32}$ dapat mempermudah proses identifikasi topik bahasan, membantu penulis dalam mendapatkan tambahan referensi yang relevan, mempermudah dalam memperoleh landasan teori terhadap pendekatan pemecahan masalah, serta membantu menelaah hasil penelitian sebelumnya guna menghindari adanya kesamaan topik penelitian.

Objek penelitiannya yaitu pandangan secara hukum islam terkait pengelolaan dan distribusi zakat serta strategi pendayagunaan zakat, sehingga dapat dihasilkan rancangan program pemberdayaan bagi dhuafa berdasarkan Fatwa MUI Nomor 14 Tahun 2011 tentang Penyaluran Harta Zakat dalam Bentuk Aset Kelolaan.

Sumber data terdiri dari sumber data primer dan sekunder. Sumber data primer didapatkan oleh peneliti melalui interaksi media komunikasi

\footnotetext{
31 Sintha Dwi Wulandari; Achma Hendra Setiawan (2018), “Analisis Peranan Dana Zakat Produkif terhadap Perkembangan Usaha Mikro Mustahik (studi Kasus Rumah Zakat Kota Semarang)", Diponegoro Journal of Ecocnoimcs, 3(1), 1-15.

${ }^{32}$ Pengertian Studi Kepustakaan https://www.transiskom.com/2016/03/pengertian-studikepustakaan.html?m=1 Diakses 17 mei 2020, $13.02 \mathrm{wib}$
} 
online dengan beberapa perangkat pada sebuah lembaga zakat ketika peneliti tengah melakukan kegiatan magang. Sedangkan sumber data sekunder berupa artikel jurnal, karya ilmiah, dan makalah terkait dengan kesesuaian hukum dalam perencanaan suatu program yang bersumber dari google shcoolar dan diakses menggunakan internet. ${ }^{33}$

Sementara pendekatan penelitian menggunakan pendekatan multidisipliner, yakni sebuah pendekatan untuk pemecahan suatu masalah dengan berbagai sudut pandang keilmuan yang relevan. Dalam penelitian ini, peneliti meninjau dari sudut pandang keilmuan manajemen strategi pemberdayaan zakat yang terdapat kaitannya dengan aspek hukum islam yang diberlakukan di Indonesia.

\section{Pembahasan}

\section{Rancangan Program Pemberdayaan Dhuafa berdasarkan Fatwa MUI Nomor 14 Tahun 2011}

Fatwa Majelis Ulama Indonesia Nomor 14 Tahun 2011 membahas terkait Penyaluran harta zakat dalam bentuk aset kelolaan. Aset kelolaan yang dimaksud dalam fatwa ini yaitu sarana dan prasana yang ada dari dana zakat dimana wujudnya secara fisik ada dalam pengelolaan amil sebagai wakil mustahik, akan tetapi kemanfaatannya tetap diperuntukkan untuk mustahik. ${ }^{34}$ Ketentuan lain terkait kegiatan ini yaitu dari sisi hukumnya, aktivitas penyaluran dalam bentuk ini diperbolehkan secara hukum namun tetap dengan memperhatikan syarat-syarat diantaranya: (1) telah tercukupinya kebutuhan mendesak para mustahik, sehingga untuk menghindari menumpuknya dana zakat yang telah dihimpun maka boleh digunakan untuk mengadakan aset kelolaan dari zakat tersebut; (2) kemanfaatan dari aset kelolaan tersebut tentunya akan dan harus kembali untuk para mustahik; dan (3) aset kelolaan boleh dirasakan kemanfaatannya oleh selain mustahik namun dikenakan pembayaran dengan ukuran yang wajar lalu dikelompokkan dalam dana kebajikan. ${ }^{35}$ Adanya Fatwa dengan ketentuan yang terkadung didalamnya tersebut membuat amil zakat tergugah untuk mengasah kemampuan kinerjanya dalam pengelolaan zakat. Dibutuhkan kompetensi amil yang mumpuni untuk dapat mengelola harta zakat tersebut dengan benar agar sesuai dengan aturan hukum yang berlaku. Mengingat bahwa aktivitas mengelola zakat terdiri dari pengumpulan, pemeliharaan, dan penyaluran maka amil harus mampu menciptakan strategi tertentu pada masing-

\footnotetext{
${ }^{33}$ Nuraeni, Irma. 2018. Pemberdayaan Potensi Sosial Masyarakat Muslim ... 89.

${ }^{34}$ Fatwa MUI No. 14 Tahun 2011 tentang Penyaluran Harta Zakat dalam Bentuk Aset Kelolaan, 4.

${ }^{35}$ Efri Syamsul Bahri; Zainal Arif (2020), "Analisis Efektivitas Penyaluran Zakat...”, 20-23.
} 
masing kegiatannya agar dalam kinerjanya mengandung nilai dan hasil yang maksimal.

Sesuai Fatwa MUI no. 14 tahun 2011 ini maka strategi yang harus dirancang adalah terkait penyaluran. Upaya realisasi ini diwujudkan dalam kegiatan menyusun perencanaan program pemberdayaan bagi dhuafa. Sekilas terkait Dhuafa, yang artinya lemah. Secara istilah merupakan golongan orang yang dalam kondisi miskin, lemah, tidak berdaya yang dapat terlihat dari segi ekonomi/ finansial, segi fisik dan psikisnya. ${ }^{36}$ Maksud dari lemah disini bukanlah karena tidak mau berusaha, tetapi karena keterbatasan dan kesulitan sehingga membuat mereka bergantung pada bantuan orang lain. Golongan yang termasuk dalam kategori dhuafa ialah anak yatim, janda, fakir miskin, budak, seorang yang muallaf, serta korban bencana. Kembali pada upaya amil dalam pengelolaan penyaluran harta zakat, perencanaan program pemberdayaan tersebut bisa dimulai dengan menyusun Masterpiece Empowerment Model (MEM) Matrix yaitu rancangan model pemberdayaan yang berisi beberapa pertanyaan kunci yang harus bisa dijawab oleh perancangan dan pengelola program pemberdayaan agar gambaran program yang akan dilaksanakan dapat terlihat dalam susunan yang rapi dan matang. Rancangan model pemberdayaan ini memuat tiga hal utama, yakni Pertama, bagaimana cara pandang dalam mengelola dan menjual program? Kedua, untuk siapa program disusun dan untuk kepentingan apa program disusun? Ketiga, bagaimana prinsip program? apakah fokus utama program? apakah telah disiapkan Exit Strateginya? Setelah dapat memberikan jawaban berupa rancangan pada ketiga poin utama tersebut maka perancang mampu untuk menentukan jenis dan nama program. Perlu diketahui juga bahwa dalam penyusunan program harus memenuhi beberapa unsur yakni SMART (Specific, Measurable, Achievable, Realistik, dan Timebound). ${ }^{37}$

Berawal dari pengalaman peneliti sewaktu melaksanakan kegiatan magang secara online disebuah lembaga zakat, peneliti berlatih menyusun strategi perancangan program pemberdayaan. Metode perancangan program yang diterapkan oleh peneliti yaitu menggunakan MEM Matrix, sehingga peneliti mampu menciptakan rancangan berikut dengan menentukan jenis programnya yaitu Pelatihan Keahlihan dan Keterampilan Digital dengan nama program yang dibuat adalah Sekolah Kilat Junior Graphic Designer Ziswaf. Beberapa poin pertanyaan yang

\footnotetext{
${ }^{36}$ Efri Syamsul Bahri; Zainal Arif (2020), “Analisis Efektivitas Penyaluran Zakat...”, 20

${ }^{37}$ Ahli manajemen Peter Drucker (1954) dalam Jurnal Aminah, Siti (2014), “Perumusan Manajemen Strategi Pemberdayaan Zakat", Jurnal Hukum Islam (JHI), 12(1): 95-96.
} 
dapat dijawab sebagai langkah penyusunan rancangan program ini dijabarkan sebagai berikut:

(1)Mengapa program ini penting bagi Dhuafa, Amil, dan Donatur? Program sekolah desain grafis ini mampu memberikan pelatihan softskil dan hardskil bagi para peserta yakni para pemuda dari kalangan dhuafa untuk mengasah kemampuan menciptakan suatu karya desain. Pelatihan ini juga dapat menjadi bekal bagi mereka untuk mendapatkan pekerjaan di era modern dengan kemampuan mengelola teknologi yang sangat dibutuhkan, harapannya mereka mampu memutus lingkaran kemiskinan dalam keluarganya hingga membuka lapangan pekerjaan untuk membantu orang lain. Dari sisi lingkungan, program ini berorientasi pada kegiatan produktif sehingga manfaat yang dirasakan berjangka panjang. Program ini disusun untuk membantu dan melatih kaum dhuafa lebih berdaya dan produktif sejak dini. Program ini tentu penting bagi amil karena di era modern ini memerlukan strategi fundraising yang penuh dengan inovasi. Program ini mampu melahirkan generasi-generasi muda yang pandai akan teknologi sehingga mempermudah lembaga zakat khususnya amil dalam menjalankan kegiatan digital fundraisingnya. Para amil juga akan terdorong untuk senantiasa mengasah dan meng-upgrade kemampuannya terkait teknologi, sehingga dapat menyalurkannya kepada peserta program. Program ini dapat menjadi alat ukur kinerja amil. Tingkat keberhasilan program ini dapat mempengaruhi tingkatan kinerja amil, kualitas kerja lembaga zakat dalam proses pengelolaan dan penyaluran, serta menambah nilai kepercayaan dimata para donatur serta mustahik. Penting juga bagi donatur karena hasil karya desain para peserta program mampu memberikan tampilan yang lebih menyenangkan dan mudah dipahami dalam marketing produk sehingga membuat donatur semakin tertarik dalam berdonasi. Hal ini merupakan salah satu upaya transparasi yang ditujukan untuk para donatur. Program ini memberikan ruang bagi donatur yang menginginkan inovasi dalam bersedekah. Dengan bersedekah pada program produktif maka donatur dapat melihat perkembangan program yang didukung secara bertahap, sehingga kenikmatan manfaat yang dirasakan bukan hanya pada saat akad donasi dilakukan akan tetapi terus terasa seiring berkembangnya program.

Selanjutnya, (2)Apakah value (nilai) yang ada dalam program? Nilai dari program adalah tergantung pada latar belakang diciptakannya program tersebut. Seperti pada program sekolah desain grafis ini, melihat era modern dengan perkembangan teknologi yang makin meningkat dan canggih tentu mengharuskan para generasi muda untuk turut berkembang maju, akan tetapi keterbatasan dalam mengakses pendidikan 
teknologi menjadikan mereka -para pemuda dhuafa- tertinggal bahkan semakin terpinggirkan di era industri 4.0. Dari sinilah program ini lahir dan berorientasi pada kegiatan produktif jangka panjang dengan konsep mempersiapkan bekal bagi para pemuda dhuafa dalam menyongsong perkembangan Era Digital \& Industri 4.0 utamanya didunia filantropi. Tujuan yang ingin dicapai dari adanya program ini yaitu menciptakan inovasi program yang produkif, memberdayakan pemuda dhuafa melalui pengetahuan dan keterampilan teknologi modern, dan memperkenalluaskan dunia Ziswaf melalui sarana digital. ${ }^{38}$ Upaya melancarkan tercapainya tujuan tersebut maka prinsip utama yang harus ada dalam program ini adalah Inovasi dan Kreatifitas. Inovasi dalam perencanaan, pelaksanaan serta tujuan, serta Kreatiftas dalam mengajak, mengajarkan, serta mengamalkan. Beberapa keterampilan yang akan diajarkan dan diperoleh para peserta meliputi kemampuan softskill dan hardskill terkait keterampilan desain grafis dengan fasilitas yang diberikan guna menunjang berjalannya program seperti tersedianya tempat/ ruang pelatihan, pengajar berkompeten, tanpa biaya/ Gratis, memperoleh Sertifikat Pelatihan dan bimbingan lanjutan setelah pelatihan bagi semua peserta, dan khusus untuk peserta terbaik akan mendapatkan bantuan modal usaha sehingga mampu mandiri dalam memperbaiki perekonomian keluarga dan lingkungan sekitarnya.

Lalu, (3)Siapakah calon peserta, calon pengelola selain amil, dan calon pendukung dalam program? Sasaran program ini yaitu para remaja dhuafa dengan maksimal usia 21 tahun dimana itu merupakan usia produktif sehingga mampu menerima pengajaran dengan mudah dan lebih cepat tanggap. Selain itu, diusia yang masih produktif mereka dapat melanjutkan pendidikan/ pelatihan lainnya untuk semakin menambah wawasan. Beberapa persyaratan untuk calon peserta seperti Yatim/ Yatim Piatu/ Dhuafa, sehat jasmani rohani dan tidak merokok, bersedia mengikuti seluruh kegiatan pelatihan secara aktif, serta memiliki motivasi, komitmen, dan semangat tinggi. ${ }^{39}$ Ada juga persyaratan administratif seperti peserta harus mengisi formulir pendaftaran, melampirkan foto copy KSK / KK, Surat Keterangan Tidak Mampu (SKTM) dari kelurahan/ lembaga sosial, dan kartu identitas KTP/ Kartu pelajar. Sedangkan calon pengelola selain amil yakni para mahasiswa dalam kegiatan magang / PKL (Pelatihan Kerja Lapangan) di lembaga zakat pembuat program, mereka dapat membantu amil memaksimalkan jalannya program dan

${ }^{38}$ Dita Afrina (2020), "Manajemen Zakat di Indonesia sebagai Pemberdayaan Ekonomi Umat", EkBis: Jurnal Ekonomi dan Bisnis, 2(2), 11-36.

${ }^{39}$ R. Hidajat (2017), “Penerapan manajemen Zakat Produktif dalam Meningkatkan Ekonomi Umat di PKPU (Pos Keadilan Peduli Umat", Millah: Jurnal Studi Agama: XVII(1), 63-84. 
menambah pengalaman. Selanjutnya untuk calon pendukung dalam program ini yakni pihak dari luar lembaga, misalkan dengan mendatangkan seorang praktisi desain grafis yang bersedia untuk menjalin kerjasama sebagai pengajar utama.

Lanjut pertanyaan ke-(4)Apa saja sumberdaya yang diperlukan dan darimana diperoleh? Sumberdaya yang diperlukan dalam program ini terdiri menjadi 6 unsur antara lain: Man (SDM) dalam program ini meliputi Perancang Program yaitu amil devisi Digital Fundraising, Tenaga Pengajar terdiri dari praktisi desain grafis dan mahasiswa jurusan desain grafis/ ilmu komunikasi dan Marketing Program oleh amil dari tim Relationship Manager; Money (sumberdaya modal) dalam program ini memang memerlukan cukup banyak biaya, akan tetapi dikarenakan program ini ditujukan untuk para dhuafa dan dijual kepada para donatur, maka sumber pembiayaan program ini yakni berasal dari dana zakat dan sumbangan donatur. Pada perencanaan biaya untuk program ini juga akan memanfaatkan dana CSR, menjalin kerjasama serta menggait sponsor dengan beberapa perusahaan elektronik khususnya perusahaan penyedia peralatan desain grafis; Material dalam program ini direalisasikan berupa objek penunjang utama dalam terselenggaranya program, seperti tersedianya fasilitas ruang pelatihan dengan aliran listrik yang memadai untuk alat-alat elektronik serta untuk penerangan dan fasilitas dokumenter seperti adanya sertifikat peserta program pelatihan dari baik dari lembaga zakat maupun dari kerjasama dengan Dinas Ketenagakerjaan; Machines (peralatan) dalam program ini tentunya banyak menggunakan alat-alat elektronik seperti Laptop/ PC, LDC Proyektor, Printer, Scanner dan alat-alat penunjang lain seperti Papan tulis, Meja dan Kursi yang diperoleh lembaga zakat dari dana ziswaf serta bantuan pihak rekan/ mitra kerjasama; Methods (metode) yang digunakan dalam mengelola unsur-unsur program ini adalah dengan memaksimalkan potensi SDM internal dan eksternal secara efektif dan efisisen. ${ }^{40}$

Sedangkan metode pelaksanaan program sekolah desain grafis menggunakan metode pengajaran secara langsung dan pendampingan teori 30\% diawal dan selanjutnya 70\% praktek; terakhir, Market (pasar) dalam program ini terbagi menjadi 2 kelompok tujuan. Pertama, untuk tujuan pemberdayaan maka market/ sasarannya adalah para pemuda dhuafa yang memiliki semangat tinggi dalam menimba ilmu dan pengalaman serta membantu meningkatkan perekonomian keluarga. Kedua, untuk tujuan fundraising zakat maka market/ sasarannya adalah

${ }^{40}$ I. Nawawi, Zakat dalam Perspektif FIqh, Sosial dan Ekonomi, (Surabaya: ITS Press, 2010), 39-80. 
donatur baik donatur tetap maupun baru juga donatur perorangan maupun kelompok/ organisasi. Utamanya adalah donatur kelompok/ organisasi yang dirasa memiliki potensi cukup besar dalam membina kerjasama yang lebih inovatif kedepannya.

Lalu, (5)Apakah indikator keberhasilan serta kapan output dari program dapat dirasakan? Keberhasilan program pemberdayaan bukan dipandang dari seberapa besar jumlah dhuafa yang diberdayakan, tetapi dari output setelah mengikuti program tersebut. Indikator keberhasilan program sekolah desain grafis ini adalah lulusan yang mampu bersaing di dunia usaha/ kerja melalui keahlihan dan keterampilan teknologi digital terutama didunia filantropi. Hal tersebut sesuai dengan tujuan program yakni memberdayakan pemuda dhuafa melalui pengetahuan dan keterampilan teknologi modern serta memperkenal-luaskan dunia ziswaf melalui sarana digital. Output yang diharapkan adalah terbukanya peluang kerja/ usaha bagi para pemuda dhuafa atas bekal keterampilan yang dimilikinya, mudahnya para stakeholder/ perusahaan dalam mendapatkan mitra kerja/ bisnis yang berkompeten dalam bidang desain grafis, serta bertambahnya ruang literasi masyarakat luas terkait dunia filantropi ziswaf melalui media digital yang semakin menarik dan mudah dijangkau.

Sampai pada pertanyaan terakhir, (6)Bagaimana strategi pengelolaan program? Strategi pengelolaan program yang dimaksud adalah termasuk cara komunikasi dengan stakeholder, cara memanfaatkan capaian/ kegagalan, serta cara mengelola program pasca pendampingan. Program ini dirancang menjadi kegiatan pelatihan menggunakan metode pengajaran secara langsung dan pendampingan teori 30\% diawal dan selanjutnya $70 \%$ praktek yang terinspirasi dari beberapa bentuk pelatihan desain grafis yang diadakan secara langsung (offline) dengan secara online diberbagai media sosial. Alur proses program ini dilakukan dalam jangka waktu +- 1 minggu selama 2-3 jam tiap pertemuan dengan rincian; 2 hari digunakan untuk pembelajaran materi dasar berupa teori. Materi yang akan diajarkan meliputi prinsip dasar desain dan komunikasi, pengenalan software grafis dan elemen grafis, serta teknik dasar grafis. Selanjutnya, 3 hari digunakan untuk pembelajaran praktek meliputi mengoperasikan perangkat lunak dan menciptakan karya desain. ${ }^{41}$

Terakhir, 1 hari digunakan untuk Ujian Akhir Pelatihan. Tujuan diadakannya ujian akhir adalah untuk mengetahui dan mengukur tingkat perkembangan para peserta serta untuk bahan evaluasi tim pelaksana dan pengajar. Data-data yang diperlukan dalam program ini disusun kedalam

${ }^{41}$ Ibid., 34. 
suatu dokumen, terdiri dari proposal kerjasama, surat izin kegiatan program, daftar mustahik/ dhuafa, daftar donatur/ mitra kerjasama, dan lain sebagainya. Agar tujuan program semakin terarah maka tim perencana program menetapkan beberapa persyaratan bagi calon peserta program. Proses evaluasi program dilakukan sejak dimulainya program pelatihan yakni oleh tim pelaksana yang rajin melakukan pengecekan pada kehadiran dan keaktifan setiap peserta melalui presensi kehadiran dan membuat tinjauan analisis ulang terhadap kesesuaian jadwal program, penggunaan waktu, bahan materi yang diberikan hingga metode yang telah disusun bersama dengan pihak pengajar dan pendamping.

Sedangkan untuk strategi komunikasi dengan stakeholder dalam program ini dilakukan oleh tim Relationship Manajer kepada para donatur, pihak sponsorship, serta pihak yang berkaitan seperti dinas ketenagakerjaan dengan melakukan analisis SWOT guna menggambarkan situasi program yang akan berjalan, membuat stakeholder mapping guna menetapkan prioritas kelompok yang perlu didahulukan dan menganalisis persepsi stakeholder dengan melakukan survei maupun membuat jadwal pertemuan untuk membenahi adanya persepsi yang mungkin kurang tahu menjadi tahu sehingga program dapat menjawab kebutuhan stakeholder. Langkah-langkah tersebut diwujudkan dalam bentuk proposal kegiatan, surat permohonan kerjasama, menggait pihak sponsorship, dan kegiatan marketing lainnya.

Sebuah pencapaian yang diharapkan dari indikator keberhasilan suatu program tentu menghasilkan manfaat. Maka dalam memaksimalkan capaian tersebut harus dikelola dengan optimal. Tim perencana program memanfaatkan pencapaian tersebut untuk membangun program lanjutan dan dapat menjadi bentuk pendampingan kepada alumni peserta program agar pemberdayaan yang diberikan lebih maksimal. Bentuk program lanjutan dapat berupa kelas pelatihan desain grafis dengan tingkatan yang lebih tinggi, seperti pelatihan membuat web, teknik pengolahan photo/ video dan materi-materi desain grafis yang lain. Sedangkan untuk kegiatan pendampingan tim perencana program dapat membantu memberikan fasilitas kepada lulusan program untuk mendapatkan posisi pekerjaan sesuai keahlihannya dan merekomendasikan kepada dinas ketenagakerjaan.

Bagi pihak pelaksana, program lanjutan dapat menjadi salah satu bentuk riil pengelolaan dana zakat, sebagai upaya transparasi terhadap donatur dan menjadi bahan marketing untuk menggait donatur baru dalam jangkauan yang lebih luas. Lalu untuk strategi memanfaatkan kegagalan adalah dengan mengambil pelajaran dari kegagalan itu sendiri. 
Memanfaatkan munculnya kegagalan sebagai upaya meningkatkan kreatifitas serta mengkaji bersama pihak-pihak yang lebih berkompeten terkait bagaimana solusi terbaik dalam mengatasi kegagalan.

\section{Kesimpulan}

Pembahasan dalam penelitian ini dapat ditelaah bahwa penyusunan rancangan program pemberdayaan dhuafa diciptakan dengan harapan untuk membantu menyiapkan bekal para dhuafa sejak dini melalui cara melatih keterampilan teknologi digital modern. Perencanaan ini dirancang dengan memperhatikan ketentuan Fatwa MUI nomor 14 tahun 2011 yang berlaku yaitu : (1) Telah tercukupinya kebutuhan mendesak para mustahik, sehingga untuk menghindari menumpuknya dana zakat yang telah dihimpun maka boleh digunakan untuk mengadakan aset kelolaan dari zakat tersebut. melihat hal ini, dalam pembahasan penelitian dirancang perencanaan program untuk dhuafa yang memiliki kemampuan produktif yang artinya mereka sedang itdak membutuhkan bantuan mendesak, akan tetapi sebelum keperluan mendesak terjadi mereka telah memiliki bekal untuk dapat mengatasinya secara mandiri kedepannya. (2) Kemanfaatan dari aset kelolaan tersebut akan dan harus kembali untuk para mustahik. Melihat hal ini rancangan yang disusun menjadi program pemberdayaan memang ditujukan untuk mereka -kaum dhuafa- dengan mencantumkan persyaratan khusus agar calon peserta program adalah golongan yang diprioritaskan. Dan (3) Aset kelolaan boleh dirasakan kemanfaatannya oleh selain mustahik namun dikenakan pembayaran dengan ukuran yang wajar lalu dikelompokkan dalam dana kebajikan.

Melihat hal ini, dalam perancangan program memang tidak ditujukan untuk kalangan umum, karena memang semua fasilitas dikhususkan hanya untuk dhuafa. Namun apabila seiring berjalannya program pelatihan membuat pihak dari kalangan umum (non mustahik) tertarik untuk turut berpartisipasi maka tentu akan dibuatkan kelas dengan kelompok tertentu yaitu dengan dipungut biaya pelatihan. Penyusunan rancangan ini dibuat tidak semata-mata hadir, melainkan dengan memperhatikan situasi dan kondisi yang ada namun belum tergali, sehingga jarang terlihat dilingkungan sekitar dan perlu untuk dieksplorasi. Mengingat juga, penyusunan ini sebagai upaya penyaluran harta zakat kearah yang lebih produktif dengan dirupakan menjadi aset yang harus dikelola berdasarkan Fatwa MUI nomor 14 tahun 2011, maka benar-benar membutuhkan strategi manajemen yang matang dalam segala rangkaian kegiatan, SDM yang berkompeten dan prinsip inovasi 
serta penuh kreatifitas dalam pengelolaan sehingga rancangan program dapat direalisasikan kemudian.

\section{Daftar Pustaka}

Afrina, Dita (2020), "Manajemen Zakat di Indonesia sebagai Pemberdayaan Ekonomi Umat", EkBis: Jurnal Ekonomi dan Bisnis, 2(2).

Aminah, Siti (2014), Perumusan Manajemen Strategi Pemberdayaan Zakat. Jurnal Hukum Islam (JHI), 12(1).

Aminah, Siti (2014). "Perumusan Manajemen Strategi Pemberdayaan Zakat", Jurnal Hukum Islam (JHI), 12(1).

Arif, Mufraini. Akuntansi dan Manajemen Zakat, (Jakarta: Kencana, 2006), 154.

Aziz, Muhammad Izzuddin Abdul; Heru Susetyo (2020), "Dinamika Pengelolaan Zakat oleh Negera di Beberapa Provinsi di Indonesia Pasa Undang-Undang No. 23 tahun 2011", Jrnal Hukum dan Pembangunan, 49(4).

Bahri, Efri Syamsul; Sabik Khumaini (2020), "Analisis Efektivitas Penyaluran Zakat pada Badan Amil Zakat Nasional", al-Maal: Jorunal of Islamic Economics and Banking, 1(2).

Bahri, Efri Syamsul; Zainal Arif (2020), “Analisis Efektifitas Penyaluran Zakat pada Rumah Zakat", al-Maal: Journal of Islamic Economics and Banking, 2(1).

Bastiar, Yandi (2019), "Model Pengukuran Kinerja Lembaga Zakat di Indonesia", ZIZWAF: Jurnal Zakat dan Wakaf, 6(1).

Beik, I .S.; L.D. Arsyianti (2016), "Measuring Zakat Impact on Poverty and Welfare Using CIBEST", Journal of Islamic Monetary Economics and Finance, 1(2).

Beik, Irfan Syauqi (2009), "Alanysis of the Role of Zakat in Reducing Poverty", Research Gate, 2(1).

Depag RI, Al Quran dan Terjemahan, Bandung: CV Diponegoro, 2000.

Dikuraisyin, Basar (2019), “Kompetensi Amil, Persyaratan Sampai Pelaporan: Analisis Efektifitas UU Nomor 23 Tahun 2011 di Lembaga Zakat Jawa Timur", MAZAWA: Management of Zakat and Waqf Journal, 1(1). 
Habib, A.A. (2016), “The Principle of Zakat, Infaq and Shadaqah Accounting Based SFAS 109", Jorunal of Acounting and Bussines, 1(1).

Hafidhuddin, Didin. Zakat Dalam Perekonomian Modern. (Jakarta : Gema Insani, 2002), 7.

Hasan, Shafiqul (2017), "Persecuted Muslim Minority: Zakat, Waqf and Sadaqah as Financial Instrument for Human Development", International Journal of Applied Business and Economic Research, 2(2).

Hidajat R. (2017), “Penerapan manajemen Zakat Produktif dalam Meningkatkan Ekonomi Umat di PKPU (Pos Keadilan Peduli Umat", Millah: Jurnal Studi Agama: XVII(1).

Khumaini, Sabik; Anto Apriyanto (2018), "Pemberdayaan Dana Zakat Produktif terhadap Kesejahteraan Umat", Jurnal al-Urban, 2(1).

Lutfi, Mustafa (2020), “Peran Negara dalam Optimalisasi Zakat Perspektif Konstitusi Ekonomi", Jurnal of Family Studies, 1(1), 7.

Mashita, Dian (2018), “Pelajaran dari Manajemen Zakat dari Berbagai Era dan Negara al-Iqtisha", Jurnal Ilmu Ekonomi Syariah, 10(2).

Nasrullah (2019), "Filantropi Islam: Praktek dan Konstibusinya terhadap Ketercapaian Sustainable Development Golas (SDGs)", in Annual Conference for Muslim Scolars, Surabaya.

Nawawi, I. Zakat dalam Perspektif FIgh, Sosial dan Ekonomi, (Surabaya: ITS Press, 2010).

Nuraeni, Irma (2018), "Pemberdayaan Potensi Sosial Masyarakat Muslim Melalui Yayasan Aksi Cepat Tanggap (ACT) Bandung". Anida: Aktualisasi Nuansa Ilmu Dakwah, 18(1).

Ridwan, Mohammad; Lilis Andalasari; Reka Indah Setiani; Rizka Merliana (2020), "Pengelolaan Zakat Produktif melalui Program Senum Mandiri dalam Pemberdayaan Ekonomi Mustahiq di Rumah Zakat Cabang Cirebon", Ecobankers: Journal of Economy Banking, 1(2).

Rosmawati, Rosi (2014), "Pengembangan Dana Zakat Produktif Melalui Lembaga Amil Zakat (LAZ) untuk Meningkatkan Kesejahteraan Masyarakat", PJIH: Jurnal Ilmu Hukum, 1(1).

Shabri, H. (2014), "Performance Comparison Amil Zakat Institutions Managed by the Government and Private Organization in West Sumatra Province", Jurnal Performance, 1(1).

Soemitra, Andri. Bank dan Lembaga Keuaga Syariah, Jakarta: Kencana, Jakarta, 2009, 403. 
Erik Rahman Gumiri, Abuzar Alghifari, Manajemen Aset Produktif...

Susilowati, Dewi; Christina Tri Setyorini (2018), “Efektivitas Tata Kelola Dana Zakat", Jurnal Akuntansi Multiparadigma, 9(2).

Undang-Undang Republik Indonesia Nomor 38 Tahun 1999 Tentang Pengelolaan Zakat

Wulandari, Sintha Dwi; Achma Hendra Setiawan (2018), "Analisis Peranan Dana Zakat Produkif terhadap Perkembangan Usaha Mikro Mustahik (studi Kasus Rumah Zakat Kota Semarang)", Diponegoro Journal of Ecocnoimcs, 3(1)

Zaini, Hafizah (2016), "Managing Zakat Fund in Malaysia”, Journal of Gloal Businiess and Social Entreprenuership, 1(2). 